\title{
SENTIDOS DO "DRAMA" NA PERSPECTIVA DE VIGOTSKI: UM DIÁLOGO NO LIMIAR ENTRE ARTE E PSICOLOGIA
}

Achilles Delari Junior

\begin{abstract}
RESUMO. Este é um texto teórico-metodológico, na acepção russo-soviética de "metodologia”. Seu objeto central é o tratamento lacunar dado por Lev Vigotski (1896-1934) à noção de "drama" em vinte e duas obras suas a que tivemos acesso até o momento (artigos, capítulos e livros completos). Em geral, a noção de "drama" em Vigotski varia entre duas acepções principais: (1) uma mais coloquial, por exemplo: "o desenvolvimento humano como drama (peça teatral) em vários atos"; e (2) outro mais específico, destacando numa ação "dramática" dois aspectos: 2.1 um ato de decisão humana sobre a condução de seu destino histórico; 2.2 o choque entre diferentes papéis que cada pessoa vivencia [perejivaet]. Estas peculiaridades constituem o caráter (in)tenso e dialeticamente conflituoso de se decidir socialmente por um caminho vital ou outro num dado contexto histórico-cultural - desde o mais corriqueiro até aquele no qual pode estar envolvida uma situação de vida ou morte - "ser ou não ser".
\end{abstract}

Palavras-chave: Vigotski; drama; psicologia.

\section{SENSES OF "DRAMA" IN VYGOTSKY'S PERSPECTIVE: A BOUNDARY DIALOGUE BETWEEN ART AND PSYCHOLOGY}

\begin{abstract}
This text has a theoretical-methodological character, in a Russian-Soviet meaning for the word "methodology". Its core subject matter is the imprecise treatment given by Lev Vygotsky (1896-1934) for the notion "drama" in 22 of his works that we could have access, until this moment (articles, chapters and entire books). Generally, the notion of "drama" in Vygotsky has two main connotations: (1) a more colloquial one: "human development as a drama in several acts", for instance; and (2) a more specific one, outstanding two major aspects in a "dramatic action": 2.1 an act of volition, human decision about the conduction of his/her own historical destiny; 2.2 the collision between different social roles that each person live through [perezhivaet]. This peculiarities constitutes the (in)tense, dialectically conflictive, of socially decide by a vital way or another, in a given historical-cultural context - since the commonest one, until that more decisive in a situation of life or death - "to be or not to be".
\end{abstract}

Key words: Vygotsky; drama; psychology.

\section{SENTIDOS DEL "DRAMA" EN LA PERSPECTIVA DE VYGOTSKI: UN DIÁLOGO EM EL UMBRAL ENTRE ARTE Y PSICOLOGÍA}

RESUMEN. Este texto es de carácter teórico-metodológico, en la acepción ruso-soviética para la palabra "metodología". Su objeto de estudio principal es el impreciso tratamiento dado por Lev Vygotski (1896-1934) para la noción de "drama" en 22 de sus obras que nosotros tuvimos oportunidad da accesar hasta el presente momento (artículos, capítulos, libros). En general, la noción de "drama" en Vygotski tiene dos principales acepciones: (1) una más coloquial: "desarrollo humano como un drama en muchos actos", por ejemplo; y (2) un acto de volición, decisión humana entre diferentes roles sociales que cada persona vivencia [perezhivaet]. Estas peculiaridades constituyen el (in)tenso, dialécticamente conflictivo, acto de socialmente decidir por un camino vital u otro, en un determinado contexto histórico-cultural. Desde lo más ordinario, hasta aquella más decisiva situación de vida o muerte - "ser o no ser".

Mestre em Educação pela Universidade Estadual de Campinas. 


\section{PROPOSIÇÃO METODOLÓGICA DE UM DIÁLOGO “NO LIMIAR" ENTRE ARTE E PSICOLOGIA}

Mikhail Bakthin, em "Problemas da poética de Dostoiévski", de 1963, fala sobre "diálogos no limiar" referindo-se a um gênero literário específico, de origem popular, no qual um intenso debate se trava, seja às portas do inferno seja às do paraíso (Bakhtin, 1963/1997). Nesse debate o herói, à beira da morte ou "pós-vida", levanta "questões últimas" da existência como Sócrates no "Fédon", que, pouco antes de tomar cicuta para cumprir sua sentença de morte, fala das origens e destino da alma humana. $\mathrm{O}$ ato de abordar "questões últimas" não é alheio ao trabalho criador de Vigotski ${ }^{1}$. Por vezes, lemos palavras solenes dele sobre o próprio destino de toda ciência psicológica, a qual estaria numa encruzilhada ou numa situação limite cujo sentido histórico cabe investigar visando à superação (Vigotski 1927/1991).

Certamente, as acepções mais correntes do termo "diálogo no limiar" no campo dos estudos marxistas da linguagem literária não serão adotadas aqui em todo o seu campo semântico; entretanto, no presente trabalho, a proposição do estudo da noção de "drama" na obra de Vigotski guarda, daquelas acepções correntes, essencialmente um sentido de "temática urgente", cuja necessidade de investigação nos convoca a tomar decisões de cunho programático para uma orientação teórica histórico-cultural em psicologia. Tal é a justificativa formal do estudo teórico-conceitual aqui apresentado; justificativa cujo aspecto substancial e pertinência social só ao leitor caberá aferir e que apenas o desenvolvimento do próprio texto poderá demonstrar, ou deixar de fazê-lo. Entenda-se ainda que ao sentido arcaico e essencial de "tema urgente", próprio ao gênero "diálogo no limiar", acrescento outro de minha própria elaboração, distinto e não divergente do anterior: o de que, em obras de Vigotski, é difícil definir se suas proposições sobre o "drama" são uma "contribuição das artes para a psicologia" ou uma "leitura psicológica de algo próprio da arte", mais especificamente, do teatro. Assim, o objeto do diálogo em si também está situado numa "região de fronteira".

\footnotetext{
1 A grafia original deste sobrenome no alfabeto cirílico russo é “Выготский”. Opto por "Vigotski", seguindo o padrão de transliteração descrito em: http://www.vigotski.net/
} obras_lsv.html\#translitera
Quer como sinônimo genérico de "teatro" ou "peça teatral", quer na acepção de "modalidade peculiar da ação humana" carregada de reflexividade e conflito interior, o "drama" situa-se em uma "região de fronteira", no limiar entre psicologia e arte. Tais elaborações iniciais sobre o motivo e o objeto da discussão aqui proposta cobram-me também uma circunscrição metodológica, mesmo que breve, da própria concepção de diálogo posta em jogo. A proposta é a de não buscar determinar um só "território" discursivo em que se situe a mais oportuna compreensão sobre o drama, como criação cultural milenar - se no campo da arte ou no da ciência. Pressuponho que a busca de um entendimento crítico seja mais da ordem da "dinâmica" (movimento, trânsito) do que de uma "tópica" (posição, área). Ao mesmo tempo, indissociavelmente, é inegável que, para movermo-nos, também é necessário partirmos de algum "lugar" e irmos em alguma "direção".

Essencialmente, conceberei o "diálogo", no sentido amplo, como modalidade mediada de relação social que, na produção de significados e sentidos, constitui-se justamente da contradição dialética entre tomada de posição e movimentação bilateral, não de modo simétrico ou harmônico, mas constituído do conflito imanente entre alianças e rupturas. Tomo ainda o "diálogo", no seu sentido mais estrito, na tarefa de investigação teórica, como uma modalidade crítica de relação entre diferentes "áreas" do saber, na qual não se abdica da árdua busca de consolidação de um campo epistemológico comum, materialista, histórico e dialético - sob a condição "sine qua non" de que no seu interior comporte confronto com a alteridade e a autocrítica permanentes. Seguindo tal orientação metodológica (i.e. metateórica) e tomando como objeto o tema acima proposto, assumo que só posso aqui colocar-me no papel social de psicólogo, isto é, de estudioso da gênese histórico-cultural do psiquismo humano, e não no de dramaturgo.

Assim sendo, dentre as opções de apontar "contribuições da psicologia para as artes" ${ }^{2}$ ou inquirir

\footnotetext{
Dentre várias contribuições possíveis da psicologia histórico-cultural para práticas sociais relativas à criação artística e ao papel da arte na vida humana, podemos citar: (1) a da "psicologia da arte", ao tratar das características propriamente estéticas de diferentes gêneros literários (e.g. Vigotski 1916/1999; 1925/1999); (2) a da "psicologia pedagógica", quando se atém à "educação estética" (e.g. Vigotski 1924/2003); e, ainda, (3) a da "psicologia do desenvolvimento" ao abordar a gênese social da "atividade
} 
sobre "contribuições das artes para a psicologia", o objetivo desse trabalho tende prioritariamente à segunda, embora a primeira não deixe de estar presente, mesmo que de modo reduzido e em segundo plano. Compreendo que, ao se aproximar de mediações culturais tradicionalmente apartadas da linguagem "científica", um psicólogo pode aguçar o olhar para sua própria condição e tarefa social e, quiçá, rumar para refazê-la e potencializá-la; mas, se é propício o dizer de Politzer: "A psicologia, para escapar de uma tradição milenar e retornar à vida, talvez deva imitar o teatro" (citado por Gabbi Junior., 1998, p. XII), também é prudente sublinhar o verbo "imitar" e não tomá-lo como "reprodução especular" reconstituição idêntica do "modelo" tal como "imagem espelhada". Melhor será assumir o gesto de "imitar a arte" como um processo social de aprendizagem, que permite tornarmo-nos diferentes do que éramos, sem desejarmos nos igualar absolutamente ao modelo, ou à "forma ideal" (Vigotski, 1935/1994, p. 348-353) que nos inspira.

Georges Politzer foi um pensador e preeminente ativista marxista de origem húngara, nascido em 1903, radicado na França e fuzilado pela Gestapo em maio de 1942, cuja esposa padeceu no campo de concentração nazista de Auschwitz. Sua obra, profícua mas pouco conhecida entre nós, teve uma recepção muito positiva na União Soviética por parte de Lev Vigotski (1929/2000, p. 26, 34, 37, 38, 39; 1931/2000, p. 89 e 96; e 1930-31/2006, p. 244). Note-se, por exemplo, que o primeiro também estudou seriamente a "crise da psicologia", a "psicotécnica" e a "nova psicologia" (Politzer, 1928-29/1947), três temas bastante importantes para o autor bielorrusso (Vigotski 1927/1991; 1931/2000). Politzer (1928/1998), ademais, dedicou muito de seu empenho teórico à crítica à chamada "psicologia abstrata", do final do século XIX, por seu tratamento artificial da vida humana, que impede, por assim dizer, que uma pessoa se reconheça como tal ao ler um texto psicológico sobre ela mesma.

Nesta direção, sempre visando ao nosso objeto de discussão, deduzimos que uma "psicologia concreta" seria tal qual aquela que "imitasse" o teatro, vindo, talvez, a nos apresentar uma realidade viva que nos diga respeito, na qual nos reconheçamos e que, principalmente, permita-nos transpor nossos próprios limites. Isso soa como uma elaboração crítica franca, instigante e inquisitiva; mas cabe questionar: como poderá a ciência psicológica assumir tal atitude junto

criadora" (оu "criação" - "творчество” [tvórtchestvo]) desde a infância (e.g. Vigotski, 1930/2009). com outra como a de que "a palavra, ao nomear um fato, proporciona ao mesmo tempo a filosofia do fato" (Vigotski, 1927/1991, p. 326 - itálico na fonte)? Respeitando esta orientação epistêmica de Vigotski, poderíamos sustentar que um texto em linguagem propriamente psicológica poderia provocar, no leitor genérico, impacto tão profundo e comovido quanto, por exemplo, o que provoca uma peça de Shakespeare ou um romance de Dostoiévski? A "filosofia dos fatos" própria da psicologia seria então uma "estética", i.e., uma "filosofia da arte"?

Se assim fosse, talvez incorrêssemos num desejo de "estetizar" em demasia a função social da psicologia, romantizando-a. Sendo assim, cabe-nos fazer, desde já, pelo menos duas ponderações, quase em tom de advertência: (1) a primeira, pouco lembrada, mas crucial, é a de que mesmo Politzer mostra não conceber a palavra "drama" de um modo "sentimentalista": "Tomamos o termo 'drama' na sua acepção mais inexpressiva, descolorida ao máximo de todo o sentimento e todo o sentimentalismo; na acepção que ele deve ter para um encenador; em resumo, na sua acepção cênica." (citado por Gabbi Junior, 1998, p. XII); e (2) a segunda, já um tanto trivial, porém necessária, é a de que, se há diferentes orientações epistemológicas em psicologia, também há várias formas de arte e de teatro - das mais realistas às mais fantásticas, das mais figurativas às mais abstratas. Tanto quanto há grupos sociais em luta, há tendências epistemológicas em luta e vertentes estéticas concorrentes, ou mesmo antagônicas, inconciliáveis.

Além disso, o próprio "efeito" da linguagem artística sobre nós pode se dar tanto pela catarse com base na "identificação" com um trajeto acidentado do herói, quanto pela tomada de consciência de aspectos até então insuspeitos da vida social, mediante profundo "estranhamento" aos signos da obra e/ou a nós mesmos em relação a eles. Ademais, se uma pessoa pode não se reconhecer num discurso científico sobre ela mesma, também pode não se reconhecer numa dada obra de arte. Conta-se, em tom de anedota, que numa exposição de Henri Matisse uma senhora se voltou para o quadro Gypsy e disse ao pintor: "Nunca vi mulher de barriga verde...", ao que ele teria replicado: "Minha senhora, isto não é uma mulher; é uma pintura". O próprio Vigotski, por volta de 1924, assumiu posição similar, ainda que noutro contexto, em tom sério e de modo sistemático: "Na arte, a realidade está sempre tão modificada que não é possível fazer uma transferência direta do significado dos fenômenos da arte para os da vida" (Vigotski, 1924/2003, p. 228). 
Destarte, mesmo que reconheçamos e respeitemos o valor ético, político e estético de diferentes iniciativas históricas da chamada "arte engajada", cabe admitir que a "crítica" não é tarefa social imprescindível para todas as formas de arte e/ou de teatro. Não é tarefa imprescindível no sentido de caber-lhes, a todo o custo, apresentar a realidade humana "como ela é" - isto é, como ela "vem a ser" em sua historicidade, seus conflitos, na dinâmica de suas contradições constitutivas. Já para uma psicologia histórico-cultural, a busca de uma abordagem crítica à realidade humana está no cerne de seu próprio projeto e compromisso social. Sendo assim, em meio à tensão entre os papéis sociais distintos da psicologia e da arte, talvez possamos interpretar o desafio lançado por Politzer quanto à necessidade de "imitarmos" o teatro, como contendo também boa dose de "ironia". Mesmo que o teatro não tenha o "dever" de nos apresentar a vida humana tal e qual, ele o tem feito até com mais desenvoltura do que a própria psicologia.

Disso não se conclui que tal ciência devesse deixar de ser crítica, mas antes, que talvez ela ainda não tenha sido suficientemente crítica. Se a busca por uma compreensão objetiva da realidade humana, pelo estudo sistemático dos "processos psíquicos superiores", restringir-se a fórmulas, esquemas ou diagramas que abstraiam seu caráter integral, dinâmico, conflitivo, contraditório - em suma, histórico -, ela poderá conduzir não à objetividade como tal, mas a uma "ficção científica", como aquela criticada por Bakthin referindo-se ao antigo modelo "emissor-mensagem-receptor" (1952-53/2000, p. 290), enquanto a arte, sob o signo paradigmático do teatro, há séculos vem indicando novos modos de olhar para nós mesmos tal como "somos", "vimos a ser" e "podemos ser" - já que, como disse Galperin para Piaget em 1966: "As coisas como elas são, constituem-se justamente num caso particular daquilo que podem ser" (citado por Veresov, 2009, p. 270).

A relação da vida e obra de Vigotski com o teatro, de modo geral, já é objeto de outro trabalho neste dossiê (Barros, Camargo \& Rosa, 2011), logo não me caberá detalhar tal temática; entretanto, um foco específico nas menções ao "drama" neste autor justifica-se, além de outras razões já citadas aqui logo no início, por isso já vir sendo posto em relevo, de algum modo, em estudos de autores renomados (Alvarez \& del Rio, 2007; Iaroshevski, 1993; Veresov, 1999, 2005 e 2009; entre outros). Assim, é num heterogêneo processo coletivo de apreciação quanto ao tema da dramaticidade da existência do homem como ser social que inscrevo o presente texto, sem o intuito de "analisar" outros caminhos percorridos, mas com o de refazer, em "diálogo com Vigotski" (Delari Junior, 2000). Deixo a avaliação crítica de seus estudos e do meu, mais modesto, a cargo do leitor. Resta dizer que não é um tema cujos significados mais sistemáticos tenham sido estritamente "definidos", mesmo por Vigotski, ao menos em seus textos mais acessíveis.

A delimitação do "lugar" deste tema, central ou periférico, no desenvolvimento atual e potencial da teoria, permanece objeto de disputas. Reitero, então, meu entendimento metodológico de que a noção vigotskiana de "drama" situa-se "no limiar", de que é um problema "na fronteira" não apenas entre "psicologia" e "arte", mas também entre a "psicologia atual" e a "futura psicologia" - ou "ciência do novo homem". Esta, por sua vez, ainda está por constituirse, já que "se parecerá tão pouco com a atual, como, segundo as palavras de Espinosa, a constelação do Cão se parece com um cachorro, animal ladrador (Ética, teorema 17, Escólio)" (Vigotski, 1927/1991, p. 406), ou tanto quanto a sociedade atual, cindida em classes desiguais e antagônicas, assemelha-se (muito pouco) a qualquer forma justa e solidária de relação coletiva entre os seres humanos, já sonhada e/ou a ser historicamente criada.

\section{ALGUNS SIGNIFICADOS DO TERMO "DRAMA" EM VIGOTSKI E EM SUAS RAÍZES GREGAS}

No espírito da problematização introdutória realizada anteriormente, esta seção se destina a apresentar ao leitor alguns dos significados sociais do termo "drama" em obras de Vigotski e em referências que permitam compreender um pouco sobre suas raízes na cultura grega antiga, com o objetivo de situar melhor a circunscrição e o potencial semânticos desta palavra (que nomeia o tema de nossa discussão) num contexto social e histórico mais amplo - o que, numa visão articulada, permite definições mais precisas. Nesta seção serão vistos três subitens: (2.1) Alguns significados gerais do termo "drama" em obras de Vigotski; (2.2) Alguns significados do termo "drama" em suas origens gregas arcaicas; e (2.3) Alguns problemas de investigação que certos significados do "drama" nos apontam.

\section{Alguns significados gerais do termo "drama" em obras de Vigotski}

É possível notar que a palavra "drama", em diferentes trabalhos de Vigotski, assume significados bem distintos, do mais geral ao mais específico. Em alguns textos se apresenta de modo quase coloquial, 
como sinônimo de "peça teatral", como quando o autor diz, em tom praticamente alegórico, que "no drama do desenvolvimento aparece um personagem novo, um fator distinto e qualitativamente peculiar: a própria e complexa personalidade do adolescente de estrutura tão complicada" (Vigotski, 1930-31/2006, p. 243 - grifo meu). Desta maneira, todo o curso do desenvolvimento ontogenético é comparado a um "drama", ou "peça teatral", e uma específica "nova formação etária” (“возрастные новообразования" [vozrastnie novoobrazavaniia]) pode figurar como "novo personagem" que "entra em cena" num determinado "ato", por assim dizer. Posteriormente, de modo explícito, aludirá aos "atos do drama geral do desenvolvimento" (Vigotski, 1932-34/2006, p. 254 grifo meu).

Em conferências pedológicas entre 1933 e 1934, Vigotski ainda apresentará a "dentição", o "andar" e a "linguagem infantil" como "atores principais e secundários desse drama" (Vigotski, 1933-34/2006, p. 338 - itálico adicionado), isto é, do drama do desenvolvimento da personalidade humana, desde bem cedo. Além dessas alusões recorrentes ao desenvolvimento como "grande peça”, encontraremos em Vigotski comparações da história da ciência com um "drama" - quando por exemplo, em sua crítica metodológica à "doutrina das emoções", dominante em sua época, afirma que se presenciava "o ato final na resolução de todo o drama científico que se iniciou em 1884-1885" (Vigotski, 1931-33/1999, p. 73); e quando se queixa de que o ocorrido "na psicologia contemporânea pode ser expresso melhor pelo choro desesperado de um dos heróis de um drama de Tchekhov" (Vigotski, 1931-33/1999, p. 198).

Essas passagens têm a finalidade de ilustrar o tema geral que nos importa, e não a de debater o rico conteúdo de cada uma delas - tarefa impossível para as poucas páginas deste simples artigo e mesmo indesejável para o leitor. Mas nelas notamos que os termos "drama do desenvolvimento", "drama científico" e "drama de Tchekhov" fazem lembrar mais "peça teatral" do que "modalidade peculiar de ação humana", ou "gênero artístico específico" no qual uma peça "dramática" pudesse se diferenciar, por exemplo, de outra "trágica", ou "cômica", etc. Sobretudo, esses termos retratam o desenvolvimento humano como transformação, ao longo do tempo, de todo um conjunto de relações sociais e do sistema de relações interfuncionais que lhes é correlato comparável ao desenrolar de um "enredo" encenado em vários "atos". Tal acepção, mais geral, não deixa de ser importante e inspiradora, mas não cobre todo o campo semântico da palavra "drama" nas elaborações teóricas do autor.

Em anotações de 1929, postumamente publicadas em russo como "Psicologia concreta do homem" (Vigotski, 1929/1986), Vigotski já indicara acepção mais específica: "O drama realmente está repleto de luta interna impossível nos sistemas orgânicos: a dinâmica da personalidade é o drama" (1929/2000, p. 35). Retomaremos este ponto adiante, mas já se nota uma noção mais específica de "drama", a qual envolve não só um processo "diacrônico" (ao longo de sucessivos "atos"), mas também uma dinâmica "sincrônica" (num mesmo instante histórico da vida humana), vista como "conflito" e "luta interior". Esse processo e essa dinâmica são tomados numa acepção inaplicável à compreensão de sistemas biológicos stricto sensu, seja à moda de "luta por sobrevivência" - como se pode interpretar de uma noção darwinista da "lei do mais forte" - seja à moda do "conflito cognitivo", entendido como uma perturbação de um estado homeostático anterior de qualquer ser vivo - como se poderia interpretar de uma noção piagetiana de "equilibração".

Ao contrário dessas duas interpretações biologizantes da noção de conflito, trata-se, na concepção de Vigotski, de algo que somente um ser humano concreto pode viver, por conta dos diferentes impasses que ele vivencia somente como ser social. Neste caso, "O drama sempre é a luta de tais ligações (dever e sentimento; paixão, etc.), caso contrário não pode ser drama, isto é, choque dos sistemas. A psicologia 'humaniza-se", (Vigotski, 1929/2000, p. 35). Estas duas acepções para a palavra drama em Vigotski, aqui apresentadas, uma mais inespecífica e quase coloquial, e a outra mais específica e com forte entonação filosófica, não são, é claro, excludentes, porém implicam focos distintos: ora destacam que "novos personagens entram em cena a cada novo ato", ou que "alguns atores têm papéis secundários e outros papéis principais", ora que "uma luta se estabelece num só e mesmo ato" - como quando por "dever" o herói da peça se portaria de um modo, enquanto por "amor" agiria de modo contrário com relação a uma mesma pessoa.

\section{Alguns significados do termo "drama" em suas origens gregas arcaicas.}

Podemos dizer que aquele "duplo aspecto" do significado social da palavra "drama" presente em obras relevantes de Vigotski tem raízes na própria 
gênese grega do teatro, mesmo que historicamente não se esgote nelas. Não obstante, entendo que apenas tentar abduzir, das pistas deixadas em textos de Vigotski, os significados sociais mais precisos e articulados para a palavra na história da cultura ocidental seria um tanto temerário - até porque, no material dele a que tivemos acesso até o momento, nenhuma vez esse autor se atém à definição categórica do termo. Por esta razão, em consonância com nossos objetivos gerais de aproximar a arte da psicologia, recorreremos aqui ao clássico Aristóteles e à estudiosa contemporânea Claire Nancy, para nos auxiliarem quanto a algumas das origens do drama.

Uma definição clássica de "drama", próxima da nossa acepção genérica de "teatro", apresenta-se numa célebre obra de Aristóteles: "A poética" (334-330 a.n.e. - 1978). Nela o "drama" está como forma de arte na qual a "representação", ou "mímese", ocorre mediante a "ação", diferindo, por exemplo, da lírica ou da epopeia (Aristóteles, 334-330 a.n.e. - 1978). "Tragédia" e "comédia" têm origens históricas diferentes, e o seu objeto de "representação", ou "mímese", também não é o mesmo; contudo, ambas podem ser consideradas teoricamente "drama", pelo modo comum de realizarem sua "mímese", ou seja, um modo "dramático" - mediante uma "ação". Em que pese a isso, estudiosos contemporâneos das práticas culturais da Grécia Antiga nos permitem perceber que o próprio significado da "ação" e/ou do "fazer" humano, naquele contexto, merece atenção especial, pois a "ação" realizada no "drama", como forma peculiar de arte, não é qualquer modalidade de "ação", mas uma intimamente relacionada com o teatro, com traços de uma reflexividade e de um conflito constitutivo similar àqueles que em Vigotski (1929/2000) também ganharão destaque.

É o que veremos no trabalho da professora de literatura grega e dramaturgista Claire Nancy (2003), a melhor referência ao meu alcance sobre o tema, dentre todas as consultadas até o momento, as quais incluem algumas notórias, como a de Augusto Boal (1975/1988), que foca mais a tragédia como sistema coercitivo, e a de Arnold Hauser (1953/1998), que foca mais o drama moderno como expressão da vida e sentimentos da burguesia nascente, entre outros. Ela explica que, com Ésquilo e o teatro, três principais verbos viriam a designar um "fazer" entre os antigos povos gregos 3.: "poïeîn", "prattein" e "drân". Os dois

$\mathrm{Na}$ Antiguidade não havia um estado nacional grego que unificasse todas as diferentes formações étnicas daquela região. A rigor, sequer havia uma "Grécia", mas diferentes unidades geopolíticas como a dos dórios, jônios, áticos, atenienses, entre outros. Alguns desses povos chegaram a primeiros teriam substantivação mais clara. Ao verbo "poïeîn" correspondem: o modo de operação "poïèsis" (substantivo ativo) e o resultado "pö̈emata" (substantivo passivo); e ao verbo "prattein" correspondemo o modo de operação "prâxis" (substantivo ativo) e o resultado "pragmata" (substantivo passivo). A "poïèsis" respeita à "criação", na qual se faz algo que antes não existia, enquanto a "prâxis" concerne a uma ação orientada a um "fim" (telos) (Nancy, 2003).

Hoje diríamos que tal distinção entre modos de fazer/agir não implica mútua exclusão, podendo mesmo indicar distintos aspectos e/ou momentos constitutivos de uma só atividade humana; mas o que mais nos toca agora é que com o verbo "drân" não ocorre uma derivação tão nítida dos substantivos relativos ao seu "modo de operação" e seus "resultados", o que indica que a "ação dramática" não se orienta a um fim específico, para além dela mesma, tampouco dela deriva claramente a criação de algo novo. Tal ação, digamos, tão somente "acontece" - no sentido filosófico de "acontecimento" como conceito constitutivo da definição de um momento histórico, \zeatanto \quanto o de "processo". Existe para o verbo "drân" o substantivo neutro "drama", mas este não cumpre função correlata aos modos de operação "poïèsis" e "prâxis", nem aos resultados "poïemata" e "pragmata". O estudo de Nancy mostra-nos "drân" como um "fazer" sempre inconcluso e em processo, por conta de sua "dupla indeterminação". Isto significa que nem seus modos de agir nem seus resultados estão predeterminados, deixando "campo livre para o que é agente da ação" (Nancy, 2003, p. 15). Aqui já se nota tratar-se de algo que "acontece" enquanto (e somente enquanto) alguém o "faz acontecer", ao que devemos hoje acrescentar "o faz acontecer com outras pessoas", socialmente.

Sabendo que a teorização especificamente vigotskiana virá logo adiante (seção 3), entendamos agora apenas que se trata de uma "ação enquanto decisão, ou comprometimento, implicação do agente. É o verbo que autoriza a distinção, introduz o jogo entre o fato de produzir um resultado (...) e o fato de decidi-lo, de assumir a livre decisão por ele." (Nancy, 2003 , p. 16). A autora não se atém a como se concebia "livre decisão" naquele momento histórico, em contraste com sua concepção a partir da Modernidade. Assumo por princípio que o próprio conceito de "liberdade" seja uma construção histórica e cultural, mas não cabe aqui detalhar este ponto. Atentaremos

disputar a "invenção" de práticas culturais importantes como o "drama", por exemplo (cf. Nancy, 2003). 
apenas para indícios de uma formulação antiga de questões que continuam vivas, justamente porque se modificam (Bakhtin 1963/1997, p. 106 - sobre o tema da "archaica"). Tais indícios estão presentes em obras literárias analisadas por Nancy e são pertinentes ao diálogo com notas programáticas da psicologia histórico-cultural, visto que, em 1932, o próprio Vigotski chegará a escrever que "o problema central de toda a psicologia é a liberdade" (1932/2010, p. 92) e que "uma grande imagem do desenvolvimento da personalidade: [é] um caminho para a liberdade. Renascimento do espinosismo na psicologia marxista" (1932/2010, p. 92-93). Vários exemplos da literatura grega antiga são dados pela autora, indicando aquela diferenciação entre o momento da "decisão" e o da "efetivação" de um ato com base no que foi decidido, ato pelo qual o herói necessita responsabilizar-se, pois não poderá atribuir sua causa nem às forças da natureza nem aos deuses ou à coação de outros seres humanos.

Isso se dá, por exemplo, quando Orestes sabe que deve matar sua mãe, Clitemnestra, por invectiva de Apolo, para vingar seu pai, Agamemnon, mas ao mesmo tempo não pode agir sem hesitar, por saber que também deverá prestar contas às Eumênides, as quais se ocupam de punir crimes familiares consanguíneos (Nancy, 2003, p. 17). Também antes o próprio Agamemnon havia passado por situação de suspensão em sua decisão de sacrificar a filha Efigênia. Por um lado, havia o vaticínio do oráculo de que sem o sacrifício da criança as naus gregas não poderiam partir para a guerra. Por outro, a ânsia por derrotar os troianos não fora ordenada pelos deuses, era um desejo das tropas comandadas por Agamemnon e dele próprio, desde o início (Nancy, 2003, p. 17). Séculos depois de Homero, tido como autor da Ilíada, na qual se passa este drama de Agamemnon, o historiador grego Heródoto colocaria entre as causas de combates e derrotas dos povos a sua "ambição" (Gagnebin, 1997, p. 21).

Há outros exemplos, mas estes são suficientes para percebermos que aquilo que se constitui como "drama" no interior dessas imagens mítico-literárias não é sinônimo de todo o desenrolar do enredo. Certamente, não poderia haver teatro sem a "poïèsis" (atividade criadora), necessária para que a própria peça viesse a existir. Também a "prâxis" (atividade orientada a um fim) está presente no teatro, representada mediante a "dramatização". Sendo assim, três modos de ação/atividade se articulam quando, por exemplo, numa tragédia a ação dos homens é submetida "a uma re-flexão, à nossa reflexão. A poesia (poïèsis) trágica é a criação da forma do questionamento do homem engajado na prâxis" (Nancy, 2003, p. 26, grifos na fonte). A ação poética não define o teatro como tal, pois não é só ele que advém de atividade criadora. Do mesmo modo, a ação práxica é objeto de "dramatização", mas em si mesma não é já teatro.

Apenas a "ação dramática" definirá o teatro como tal, donde uma sustentação lógica para a metonímia da parte pelo todo: a palavra "drama" está usada para significar próprio "teatro" como arte, tanto na composição do texto quanto em sua encenação. É o que interpreto das últimas palavras do texto de Claire Nancy: "drân não produz nada, diferentemente do modo poético ou do modo práxico, mas apenas sua própria representação reflexiva, que nós chamamos teatro" (2003, p. 27). Abrevia-se assim nossa compreensão inicial do termo "drama": ele é a própria arte teatral, forma estética na qual situações de decisão e de comprometimento do ser humano com relação às suas ações são apresentadas ao público na qualidade de objeto de reflexão moral não só do herói, mas de todo o público. Ele não cria nada de "objetificado", mas produz significados e sentidos.

\section{Alguns problemas de investigação que certos significados do "drama" nos apontam.}

O leitor mais atento notará que o estudo de Nancy nos esclarece, sobremaneira, vários aspectos conceituais que compõem o debate sobre nossa temática, tanto quanto perceberá que este mesmo estudo engendra novos problemas para a investigação. De modo instigante, não linear, ela nos põe diante de um intrincado "jogo de espelhos" no tocante à psicologia, por dar a ver relações recíprocas e assimétricas entre "drama" e "vida". Assimétricas porque a vida contém o drama, não se encerra nele, embora seja nele recriada e ampliada, transbordando seus contornos habituais. Justamente por isto, vale perguntar: se o drama é uma forma artística definida como composição e desempenho de uma ação deliberada (não antes determinada) que só produz sua própria representação, hoje chamada "teatro", como interpretar a afirmação de que "a dinâmica da personalidade é o [um] ${ }^{4}$ drama" (Vigotski, 1929/2000, p. 35)? Se a personalidade for como uma obra de arte dramática, quem será o autor/criador que escreve a peça?

\footnotetext{
Vale lembrar que a língua russa não possui a classe gramatical "artigo", nem o definido, nem o indefinido. Desse modo, se tivermos "o drama", "um drama" ou apenas "drama" será uma opção do tradutor, exceto quando "um" for numeral.
} 
Nota-se que não há uma equação perfeita, pois se dá em momentos distintos da realidade humana: $(a)$ como criação artística, o drama (classicamente) precisa antes ser escrito para então ser exibido ao público (Guénoun, 1992/2003); (b) como sistema singular de processos psíquicos, a personalidade não foi antes "escrita" (prescrita) por outros, nem por nós: ela se produz e é produzida ao "atuarmos" na cena viva de nossas relações sociais, que são "a fonte do desenvolvimento e não o seu cenário" (Vigotski, 1935/1994, p. 349). Pode-se acrescentar que tal "espelhamento" assimétrico e refratário se desdobra, por ser o "drama", como criação cultural, algo "recente" na longa trajetória da humanidade, ainda que suas raízes mais arcaicas não possam ser noticiadas com exatidão. Nesse caso, a pergunta será: supondo-se que só na Grécia Antiga uma "decisão humana" obteve, pela primeira vez, estatuto de objeto e modo de representação artística, diríamos que antes ou algures as deliberações não eram nem são "drama"?

Cabe-me marcar aqui meu entendimento de que não basta supor que certas realidades socioculturais só "existem" quando são claramente "nomeadas". Ora, dizer, por exemplo, que "até o fim do século XVIII a vida não existe” (Foucault, 1966/1992, p. 175) não é negar ter havido "vida" como tal, mas tão somente tornar impactante algo óbvio, que se traduziria em linguagem mais direta por uma frase como: "a concepção genérica de 'vida' surgida no século XVIII, não existia antes desse período". Tal retórica, que aqui critico, recobre superficialmente a noção acertada de que mesmo dizer "a vida como tal" já é fazer uma abstração moderna, historicamente produzida - algo que, na aparência, convergiria com a psicologia histórico-cultural se indicasse que a mediação cultural dos significados das palavras, em diferentes momentos históricos, transforma-se em função das práticas e lutas sociais que constituem esses significados e transformam essas palavras, mas na realidade divergirá.

Explique-se: para a "arqueologia" do autor francês "numa cultura e num dado momento, nunca há mais que uma epistémê, que define as condições de possibilidade de todo o saber" (Foucault, 1966/1992, p. 181). Tal análise vê as lutas sociais como algo secundário e propõe-se a proceder "sem levar em conta personagens nem sua história" (idem, p. 216). Essa busca por "regimes de signos" entendidos como estruturas autocontidas e impessoais que constituem um solo epistêmico único, pré-condição para quaisquer convergências ou divergências, opõe-se diametralmente tanto à concepção marxista de que "toda a história - desde a dissolução do regime primitivo de propriedade comum da terra - tem sido uma história de luta de classes" (Marx \& Engels, 1872/2004, p. 13), quanto à de que "em todo signo ideológico confrontam-se índices de valor contraditórios. O signo se torna a arena onde se desenvolve a luta de classes" (Bakhtin [Voloshínov], 1929/1992, p. 46, itálico na fonte).

Como todos os estudiosos mais sérios da Psicologia Histórico-Cultural assumem e como também o presente dossiê retoma de modo enfático (Romanelli, 2011), a matriz epistêmica nuclear de Vigotski é dialética, jamais pós-estruturalista, como a do autor francês anteriormente citado, o qual é um exemplo apenas, entre tantos possíveis, desta vertente idealista que distorce e hipostasia a função da linguagem e do poder nas relações sociais. Vigotski não faria hipostasia similar com relação à linguagem artística, para conceber, hipoteticamente, que, até os gregos "inventarem" o teatro, a personalidade "não existia". Seria uma distorção por omissão de sua redundância, pois "o teatro inventado pelos gregos, em todo caso, foi o teatro grego", não se podendo concluir, por toda a lei, que este seja o primeiro - nem o único - povo que realizou ritos públicos "dramatizando" decisões de alguém quanto a situações vitais de interesse para o seu destino e o de sua coletividade, mesmo que não se chamassem "drama".

Conforme os sentidos que se realcem para "invenção", o relativismo pós-estruturalista desdirá até mesmo sua retórica de suposta abertura à alteridade, compactuando com uma velha e aristocrática "exclusividade" etnocêntrica: (a) "se o teatro é algo só grego, então nunca houve teatro antes, nem em outro lugar"; (b) "se o teatro é algo só grego, então todo teatro que houver em qualquer tempo e lugar será grego". Isto seria um "fundacionismo" na gênese de gêneros discursivos mais uma vez inconciliável com a elaboração teórica de autores de orientação dialética como Bakhtin, para quem "O gênero sempre é e não é o mesmo, sempre é novo e velho ao mesmo tempo. $\mathrm{O}$ gênero renasce e se renova em cada nova etapa..." (1963/1997, p. 106). Não posso recuperar aqui, mesmo abreviando, uma gênese histórica de diferentes gêneros dramáticos e seu possível influxo de sentido nos escritos de Vigotski, mas se deduz que sua contribuição específica acerca do caráter dramático da existência do homem como ser social, da qual tratarei a seguir, mantém e modifica noções "gregas" até aqui apresentadas. 


\section{ACERCA DE LUGARES PARA O "DRAMA" EM TRABALHOS DE VIGOTSKI}

Como anunciamos nas seções anteriores (necessárias para bom entendimento do que segue), passaremos agora ao núcleo do nosso trabalho, que trata da especificidade da contribuição de Vigotski quanto à milenar criação cultural que é o "drama”. $\mathrm{O}$ objetivo será resgatar tal contribuição buscando as suas aproximações com a construção futura de proposições mais apuradas para a compreensão histórico-cultural quanto à gênese social da personalidade. Tal busca será conduzida passando-se ao longo de alguns momentos históricos da trajetória do autor, categorizados, para fins de exposição, em três subitens: (3.1) No período anterior à sua entrada "oficial" na psicologia; (3.2) No período "reflexológico" de sua produção em psicologia; e (3.3) No período da "Teoria histórico-Cultural" propriamente dita.

\section{No período anterior à sua entrada "oficial" na psicologia.}

Algo de "teatral" se pode resgatar na biografia de Vigotski já antes de concluir sua faculdade, não apenas como leitor e/ou expectador de dramas, mas também como "ator" em seu círculo de amigos. Dobkin (1982/2009) conta que seu amigo Lev Semionovitch, nas férias de 1915 ou 1916, participou de um "júri simulado", no qual foi julgado um personagem literário de Vsevolod M. Garshin (18551888). Quando a Vigotski foi perguntado se preferia representar o papel de advogado ou de promotor, ele teria respondido que não se importava, pois estava preparado para defender os dois pontos de vista. Ele teria "adquirido esta abordagem à análise dos casos como estudante de Direito" (Dobkin, 1982/2009, p. 21) - algo cujos princípios, de algum modo, são assimilados pelo que pedologistas russos chamaram de "método da colisão" [metod kollizii], no qual os sujeitos são convidados a levantar igualmente argumentos favoráveis e contrários às suas próprias ações ou atitudes - conforme Ipain (em comunicação coletiva em 10.02.2010).

O leitor de Vigotski notará nesse episódio um “ar de semelhança" com o modo usual de ele reconhecer importantes contribuições de seus interlocutores, para em seguida apontar seus limites e então indicar outras possibilidades para abordar determinado tema. Nas palavras de seu amigo: "Toda sua carreira científica foi marcada por sua extraordinária habilidade para compreender não apenas as coisas com as quais ele mesmo poderia identificar-se, mas também o ponto de vista do outro" (Dobkin, 1982/2009, p. 21). Tal jogo de papéis distintos, no qual se assumem pontos de vista até mesmo antagônicos e mutuamente excludentes, faz lembrar relatos de momento anterior na trajetória de Vigotski, bem antes de necessitar apropriar-se dos recursos retóricos próprios ao exercício da advocacia. Refiro-me à sua instrução particular com Salomon Markovitch Ashpiz, que, ao que consta, dominava a dialética socrática (Wertsch, 1985; e Friedgut \& Kotik-Friedgut, 2008, p. 19-20).

Sócrates buscava, com a "maiêutica", contribuir para que seu interlocutor encontrasse um caminho "por si mesmo" e, com a "ironia", apresentar em seu próprio discurso um erro lógico desta pessoa, para que ela o percebesse primeiro em Sócrates e só então tomasse consciência de que era antes seu próprio erro. Há nisto uma assimetria, pois nem toda opinião [doxa] é sabedoria [sophia] e nem todas são "igualmente válidas" - o que está mais para "relativismo sem qualquer verdade" dos sofistas do que para "busca dialógica da verdade" do Sócrates das ruas (Bakhtin, 1963/1997). Por outro lado, nesta busca há também uma atitude de descentramento, pois na maiêutica devo encontrar no interlocutor algo que ele já sabe, mesmo que haja o que ainda não veio a saber, e na ironia devo trazer para mim algo que o outro ainda desconhece, mesmo que daquilo eu já tenha conhecimento. É preciso se colocar no lugar do outro, por princípio e método, só que a finalidade não é validar qualquer posição, mas produzir, na tensão do debate, uma compreensão conceitual condizente com a realidade.

Por conta desta impossibilidade de indiferença quanto a qual seria a posição mais verdadeira no diálogo socrático arcaico, minha interpretação não coincide com a de Dobkin (1982/2009, p. 21), citada há pouco. Noto que Vigotski não só reconhecerá a contribuição científica de seus oponentes, mas ainda divergirá deles abertamente, dispondo-se a se colocar à prova crítica, pois não mostra desejar "agradar a gregos e troianos". Haverá confronto, choque, "colisão", mas não será mais indiferente estar como "advogado" ou "promotor", pois estará em jogo algo que, em carta a Luria, Vigotski diz ser primordial para si: "a questão da verdade". Ele escreve, de modo resoluto, que "a questão primária é a questão do método; esta é para mim a questão da verdade" (Vigotski, 1926/2007, p.18). Problemas heurísticos, i.e., referentes à produção de meios de cognição fidedignos no tocante às contradições do real, são recorrentes em Vigotski (1925/1999, cap. 1; 1927/1991; 1931/2000, caps. 1 a 5; 1934, cap. 1 ; etc.). 
Retornando ao período universitário do autor bielorrusso, vejamos se não há também algo de "colisão" na vivência de Hamlet, herói da tragédia de igual nome, objeto de sucessivos estudos de Vigotski - dentre os quais Tamara Lifanova (1996) registra um manuscrito de 5/8 a 12/9/1915 (sem volume definido) e outro de 14 a 23/2/1916 (em 12 cadernos). Tal herói também se situa entre alternativas opostas, embora permaneça suspenso e inativo diante delas até o desfecho da peça. No conhecido monólogo do Ato III, cena I, o herói coloca para si "questões últimas" quanto à existência. Constatando as misérias da vida, na qual sofremos com "as injustiças dos mais fortes, os maus-tratos dos tolos", cogita "obter sossego com um punhal", mas hesita. Nisso duas tendências "colidem": por um lado, a morte é apenas sono; por outro, ninguém sabe "os sonhos que poderá trazer o sono da morte" (Shakespeare 1601/1990, p. 74).

O príncipe da Dinamarca apresenta esta atitude de inação ou indecisão que Vigotski identifica como uma característica própria à "vivência mística" [“мистическое переживание" [mistitcheskoe perejivanie]) do herói: a "inatividade da vontade" nos termos de William James (citado por Vigotski, 1916/1999, p. 225, itálico na fonte); mas mesmo com as "sombras" que envolvem a tragédia, nela se insinua algo ligado ao "esclarecimento" ou sua busca: o problema das decisões humanas e em que valores éticos e étnicos estas devem se pautar. Tal problemática é tanto "precoce" em Vigotski - como em seu interesse pelo problema do "papel do homem na história" (Jaan Valsiner, em comunicação coletiva, 12.06.1992) - quanto "tardia" - como em seus estudos psicológicos posteriores, ao tratar do "ato volitivo" (Vigotski, 1931/2000, p. 285-302), ou ao afirmar que para a mais profunda compreensão do significado de um enunciado é necessário tomarmos em conta sua causa "afetivo-volitiva" ("аффективно-волевой” [affektivno-volevoi]) (Vigotski, 1934, p. 314, itálico adicionado).

A "volição" será justamente tratada como ato de "eleição" ou "escolha" entre ações e/ou caminhos distintos, mas igualmente possíveis e viáveis não apenas em "imaginação". Se para escolher precisamos ter mais que uma opção, como haveria volição sem pairar sobre nossas consciências qualquer "sombra" de dúvida? Em contradição com a inatividade sombria da vivência mística insinua-se a possibilidade de produção e composição social, de uma ação livre e esclarecida do homem na condução de sua história, como processo social tenso, dramático, repleto de escolhas entre agir ou não agir - "ser ou não ser" (Shakespeare, 1601/1990, p 73). Tal contradição dialética, no meu entendimento, é imanente ao "salto para adiante, do reino da necessidade para a esfera da liberdade, como descrito por Engels" (Vigotski, 1930/1994, p. 182) - o que se faz necessário tanto para "toda a sociedade quanto para a personalidade individual" (idem, p. 182) - em consonância com nossa formulação anterior.

\section{No período "reflexológico" de sua produção em psicologia}

Desde seus primeiros escritos sobre Hamlet, vários anos passarão até que Vigotski se pronuncie de modo mais explícito no gênero da investigação científica em psicologia. Em seus primeiros trabalhos "psicológicos" ele se aproximará e distanciará da reflexologia da época. Indício disto é que critica o "idealismo" de Pavlov, por este admitir a especificidade do "psíquico" sem lhe aplicar seu próprio método (Vigotski, 1924/1991, p. 17), e conclui que se deve "ser mais reflexólogo que o próprio Pavlov" (idem, p. 18). Nessa linha, defende tomarmos a consciência, processo psíquico propriamente humano, como objeto de estudo da psicologia objetiva; mas afirma que os processos conscientes não são só um reflexo, nem mesmo um "sistema de reflexos", e sim, um "mecanismo de transmissão entre sistemas de reflexos" (Vigotski, 1924/1991, p. 11, itálico na fonte). Esta complexidade é abreviada pela definição de consciência como "reflexo de reflexos" (Vigotski, 1924/1991, p. 18).

Esta definição é repetida no texto "A consciência como problema da psicologia do comportamento": "No contexto dos excitantes se trata do mundo, no de meus reflexos, da consciência. Esta é unicamente um reflexo de reflexos" (Vigotski, 1925/1991, p. 59). É preciso destacar que a noção de processo de "segunda ordem" também se apresentará com termos da "velha psicologia" (subjetiva), na definição de consciência como "vivência de vivências" [perejivanie perejivanii] (Vigotski, 1925/1991, p. 50). Assumindo uma "dívida intelectual" com a linguagem da época, mas também em luta constante por superá-la, Vigotski mostra manter em seu subtexto algo relativo ao problema do "ato volitivo", o qual se insinua na objetividade do fato neurológico, constatado por Sherrington, de que temos muito mais neurônios para receber estímulos do que para emitir respostas. Se não podemos responder a todos os estímulos advindos do mundo (exterocepção) e de nós mesmos (propriocepção e interocepção), o que prevalecerá?

Num "efeito funil", tais estímulos "lutam" pela "possibilidade de serem respondidos", até que uma 
das "repostas possíveis" vença após se chocarem num "ponto de colisão" (Vigotski, 1925/1991, p. 47). O mesmo fato neurofuncional é tomado como base para o entendimento da "reação estética" na "Psicologia da Arte", obra do mesmo período:

O princípio da luta pelo campo locomotor geral, estabelecido por Sherrington, mostrou que o nosso organismo está estruturado de tal modo que os seus campos receptores nervosos [aferentes] superam em muito os seus neurônios eferentes [efetores], resultando daí que o nosso organismo percebe muito mais atrações e estímulos do que pode realizar [responder]. (...) O mundo deságua no homem pela boca de um funil através de mil apelos, atrações, uma parte [quantitativamente] insignificante desses elementos se realiza como se escorresse para o bico do funil. (Vigotski, 1925/1999, p. 312).

Nesse momento de sua trajetória intelectual, Vigotski toma as relações entre "arte e vida" nos termos de um "excedente" de atrações e estímulos não respondidos que, supostamente, precisaria ter alguma "descarga", a qual poderia ser proporcionada pela relação do homem com a obra de arte. Embora no mesmo livro ele critique a "interpretação energética" de Freud (Vigotski, $1925 / 1999$, p. 295), por não contemplar a especificidade da criação de um artista, permanece um tanto refém da noção de "reação estética", concebida em termos energético-reflexológicos, por assim dizer.

Não obstante, a contribuição mais radical de Vigotski neste no livro "Psicologia da arte" é a de mostrar que o essencial na obra de arte seria ela estar objetivamente organizada pelo artista para mobilizar em nós reações simultâneas em direção contrária, as quais irão colidir em nossa vivência emocional, transformando nossos sentimentos. Assim ocorrerá ao lermos, por exemplo, um conto como "Hálito leve" [Legkoe dikhanie] de Ivan A. Bunin (1870-1953).

O enredo de tal conto, um tanto banal, evocará um dado sentimento, enquanto a forma de desenvolvê-lo, numa narrativa não linear, produzirá um sentimento oposto - ao mesmo instante. Seria uma forma social de organização da linguagem literária que nos conduz a um "ponto crítico", ou "ponto de culminância" de uma síntese dialética, um momento de "salto de qualidade", no qual se inverte a habitual "correlação de forças" entre nossos sentimentos. Nesse sentido, a noção vigotskiana de arte como "técnica social do sentimento" (Vigotski, 1925/1999, p. 3, itálico na fonte) se amplifica na afirmação: "A arte é o social em nós, e, se o seu efeito se processa em um indivíduo isolado, isto não significa, de maneira nenhuma, que as suas raízes e essência sejam individuais" (idem, p. 315). Por conta da discussão sobre o caráter dramático da existência humana, meu foco, neste momento, está mais na "luta" apresentada pelo autor do que em suas tentativas de teorizar seu eventual "apaziguamento".

Essa luta entre "atrações" opostas, na vida coletiva, na linguagem da obra, ou na vivência mais íntima de um só indivíduo, é, de algum modo, sempre social; mas oscila e luta também Vigotski entre atrações da explicação energéticoreflexológica e da compreensão marxista da arte como atividade social. Assim, "Psicologia da arte" deixa questões por reelaborar, ao mesmo tempo em que anuncia incursões futuras do autor, como o problema da relação entre afeto e volição, visto que a "vida concentrada na arte não influencia apenas os nossos sentimentos como também a nossa vontade" (Vigotski, 1925/1999, p. 316). O tema da "vontade", também nomeado aqui como o da "volição" e/ou do "ato volitivo", está relacionado com a noção de drama, como vimos, e terá uma maior elaboração nos trabalhos posteriores de Vigotski, no período de seu trabalho criativo em que se definem as teses principais da Teoria Histórico-Cultural propriamente dita.

\section{No período da Teoria Histórico-Cultural propriamente dita}

Estudiosos têm mostrado que só a partir de 1928 se articula na obra de Vigotski, em colaboração com A. R. Luria (1902-1977), uma proposição mais nítida da Teoria Histórico-Cultural stricto sensu. Andrei Puzirei, por exemplo, nomeia o texto "O problema do desenvolvimento cultural da criança" (Vigotski, 1928/1994) como sendo o "manifesto" da Teoria (Puzirei, 1989, p. 42); e entre outras importantes teses, destaca o papel do uso de "signos", ou "instrumentos psicológicos", como mediadores culturais da atividade humana, constitutivos dos processos psíquicos superiores em sua gênese social. Esse tema está também presente noutras importantes obras nos anos seguintes, como "Instrumento e signo" (Vigotski \& Luria, 1930/2007), "História do comportamento" (Vigotski \& Luria, 1930/1996) e "História do desenvolvimento das funções psíquicas superiores" (Vigotski, 1931/2000), com base na noção de que 
entre um estímulo direto e a resposta que daremos a ele, interpomos ativamente outra modalidade de estímulo, um "signo", como mediador: "S-X-R".

Esta estrutura mediada é algo até então inédito, e sugere a possibilidade de o ser humano conquistar, ao longo de sua história de desenvolvimento, a capacidade de intervir ativamente na eleição ou escolha de quais "atrações" ou "apelos" devem ser ou não atendidos. De 1929, um ano depois do "manifesto" e pouco antes daquelas três obras hoje tidas como pilares da Teoria Histórico-Cultural, datam anotações programáticas de Vigotski, publicadas na Rússia em 1986, com o título: "Psicologia concreta do homem" (1929/1986; 1929/2000). Nesse texto a analogia pavloviana do funcionamento da atividade nervosa superior com uma "rede telefônica" é contraposta pela metáfora do homem consciente como "telefonista" (Vigotski, 1929/2000, p. 31-32). Ambas as imagens foram retomadas no livro, datado de 1931, sobre "A história do desenvolvimento..." (em parte publicado em 1960; e em 15 capítulos só em 1983), que destaca a necessidade histórica de considerar o "trabalho do telefonista" (Vigotski, 1931/2000, p. 91).

De todas as fontes por nós consultadas até o momento, "Psicologia concreta do homem" é o texto de Vigotski que mais cita a palavra "drama" (21 vezes). No interior do próprio texto seu significado flutua entre, principalmente, duas acepções. A primeira, mais genérica, é a do "drama" como um "jogo de papéis" ou "encenação teatral”, como se diferentes funções psíquicas, entre as quais certas emoções humanas, fossem os "atores". Nestas passagens, o ser humano é posto quase como "arena" de seu próprio drama, e à psicologia cabe perguntar sobre qual seria "o papel da paixão, da avareza, dos ciúmes, em uma dada estrutura da personalidade" (Vigotski, 1929/2000, p.34). Nesta linha, diferentes orientações teóricas em psicologia são comparadas a gêneros dramáticos particulares, segundo o modo pelo qual os "atores" (processos mentais) jogam seus papéis (cumprem "funções"). A velha psicologia é um "drama com papéis fixos", e na nova psicologia existe "mudança de papéis" (Vigotski, 1929/2000, p. 36).

Nesta linha argumentativa alegórica, muito comum em Vigotski, isto significa que, na "nova psicologia" (psicologia objetiva), um "ator" como um "sonho", digamos, pode representar papéis diferentes, por exemplo, na vida de um neurótico ocidental que passa por uma terapia psicanalítica ou na de uma pessoa alheia a isto em cuja cultura seus sonhos sejam vistos como fonte de decisão para seu destino. Diferente desta apresentação de funções mentais como "atores", temos em Vigotski uma segunda acepção, mais específica, embora articulada com a primeira: a do drama no qual o próprio ser humano, como ser social, é o "ator". Será assumindo determinado papel social, no drama das suas relações com outras pessoas, que alguém viverá aquele outro "drama", o de suas funções psíquicas. Um exemplo hipotético é o de um juiz que deve julgar a própria esposa: (a) "como pessoa simpatizo, como juiz condeno"; (b) "sei que ela é má, mas eu a amo"; (c) "simpatizo, mas condeno, o que vencerá?” (Vigotski, 1929/2000, p. 37).

Vigotski fala, a propósito dessa situação fictícia, de duas "hierarquias" ou "estruturas" (cf. Vigotski, 1929/2000, p. 36): em "a" o pensamento sobrepõe-se aos desejos [P/Ds]; e em "b" os desejos sobrepõem-se ao pensamento [Ds/P]; porém o drama do homem reside no choque entre as duas hierarquias, tal como vividas no exercício de dois papéis sociais antagônicos: "juiz" [P/Ds] $\leftarrow \mathrm{X} \rightarrow$ [Ds/P] "esposo". Qual deles vencerá: o de magistrado imparcial ou o de esposo amoroso? $\mathrm{Na}$ linguagem taquigráfica das anotações de Vigotski, sintetiza-se: "Eu: sobre a psicologia dos papéis. Compare Politzer: o drama. O papel social (juiz, médico) determina a hierarquia das funções, isto é, as funções mudam a hierarquia nas diferentes esferas da vida social. Seu choque = o drama." (1929/2000, p. 37, itálico na fonte). Tal formulação é o ápice da solução teórica do problema por Vigotski, nas condições históricas que lhe couberam, embora nos fique a tarefa de desenvolvê-la e produzir suas aplicações práticas.

De toda maneira, tal situação de "julgamento" não pelo "juiz", mas pelo homem ao decidir se deve agir socialmente como "juiz" ou "marido", não nos soa fortuita, já que algo similar se passa nos exemplos da literatura grega a que recorremos antes. Como guerreiro grego, guiado por Apolo, Orestes deve matar a própria mãe para vingar a morte do comandante; como um filho, sujeito à ira das Eumênides, não deve fazê-lo, para evitar severa punição. O que prevalecerá? É muito rica a proposição de Vigotski de que em diferentes culturas nossas funções mentais assumirão diferentes "papéis", terão diferentes sentidos - e.g. a diferença entre o ciúme do ocidental e o "de uma pessoa relacionada com os conceitos maometanos de fidelidade" (Vigotski, 1930/1991, p. 87). Isso se amplia, pois os valores dos sistemas de funções 
mentais também mudam para pessoas que assumem diferentes papéis sociais numa mesma cultura.

Poderíamos imaginar, num exemplo abstrato, que a função complexa e mediada de "orientação espacial", para um taxista que deseja chegar a um ponto específico na cidade em que trabalha, pode ser importante, mas não tão relevante para um turista procurando um monumento histórico numa cidade desconhecida - caso, digamos, ele possa contar com um taxista que o leve até onde deseja ir. As implicações desta formulação se ampliarão ao admitirmos que mais que um papel se choca, colide em nós num mesmo momento e situação social, numa mesma vivência, única e contraditória - e.g. como pesquisador devo viajar, e cumprir minha função cidadã, mas como pai quero ficar aqui e poder dar carinho ao meu filho; como filho devo ficar aqui para cuidar de meus pais já idosos, mas como enamorado quero viajar para encontrar a moça de quem gosto, etc. Assim, dizer que "a dinâmica da personalidade é drama” ultrapassa a imagem da "peça em vários atos".

A "dinâmica" nesse caso não é apenas movimento da personalidade "fazendo um percurso", mesmo que "microgenético", por sucessão ou alternância de eventos vitais no transcorrer do "ato", mas o percurso de tal ato é uma metáfora para um estágio/período ou um capítulo/episódio passíveis de serem registrados e/ou transcritos, de modo encadeado numa dada sequência ou linha, numerada por turnos ou não... Além desta "dinâmica", traduzível pela categoria filosófica da "duração", a qual de fato compõe qualquer gênese histórica, trata-se também de pensar tal palavra em acepção distinta e não excludente. Qual seja a "dinâmica" como movimento dialético de colisão, contradição, mútua aniquilação e recriação entre possíveis trajetórias distintas ou opostas, em intensa coexistência, num "acontecimento" (em russo "событие" [sobitie]) para um tratamento rigoroso desta categoria filosófica, da qual aqui me valho de modo apenas genérico -, veja-se, o trabalho de Bakhtin (191921/1997).

Outra amostra emblemática de que Vigotski está, com a Teoria Histórico-Cultural, em pleno movimento de superação do paradigma reflexológico por ele mesmo em parte assumido, até momentos anteriores, é a alegoria (praticamente anedota) do “Asno de Buridan”. O asno está com fome e a igual distância de duas moitas de capim do mesmo tamanho, e por funcionar apenas por "estímulo e resposta", morre de fome, já que uma resposta anula a outra e ele fica paralisado... Diz Vigotski que com o ser humano isso jamais aconteceria, pois poderia "jogar uma moeda" e decidir com base nesse recurso cultural, nesse signo que ele mesmo utiliza para regular seus atos e decidir qual caminho tomar (Vigotski, 1931/2000, p. 70). Este já é, por si, um exemplo bastante contundente de superação do paradigma respondente "S-R"; mas, para além desse avanço, o próprio modelo de signo de Vigotski vai tornar-se mais elaborado, o que nos permitirá visualizar elevações quanto à questão da volição e do drama próprios a cada processo de significação produzido pelos seres humanos em suas relações sociais.

Vigotski assumirá, entre 1933-1934, que, "se antes nossa tarefa era mostrar o [que há de] comum entre o 'nó' e a memória lógica, agora consiste em mostrar a diferença que existe entre eles" (Vigotski, 1933-34/1991, p. 121) - e desta maneira pôde deduzir que de seus trabalhos acumulados "se depreende que o signo modifica as relações interfuncionais" (idem, p. 121). Também poderíamos deduzir que, mediante a transformação de tais relações, o signo também se modifica. Vigotski, no seu último texto conhecido (Blank, 1984), "Pensamento e palavra", fará grande esforço para produzir, como testamento intelectual, caminhos metodológicos de análise genética e funcional das relações entre a fala social desdobrada, pronunciada, e a fala interior, também social por definição. A interfuncionalidade é, nesse momento, fundamental. Para interpretar a fala é preciso compreender o pensamento, e para compreender o pensamento cabe buscar suas causas afetivo-volitivas (cf. discutido anteriormente).

Por fim, a tematização do "drama" estará presente no capítulo final da obra "Pensamento e Linguagem" de mais dois modos: (a) na analogia com as relações entre "texto" e "subtexto" no teatro de Konstantin Stanislavski (cf., neste dossiê: Barros, Camargo, \& Rosa, 2011); e (b) em sua alusão provocativa ao "drama vivo do pensamento verbal" (Vigotski, 1934, p. 315). O autor alude ao caráter "dramático" da nossa "linguagem interior" sem, porém, explicitar se isto é no sentido de tal pensamento ser "em vários atos", de comportar o confronto entre "vários atores", ou de ser algo que envolve conflitos entre diferentes sentidos e significados que uma só palavra pode ter para/em nós, exigindo-nos assim uma "decisão", "ato volitivo", no instante de compreender e responder cada palavra que nos é dirigida, já que as 
"atrações" são muitas. O "drama vivo do pensamento verbal" (repleto do conflito da própria vida), visto na direção da verbalização, pode ganhar também dimensões sociopolíticas, pois em muitos momentos somos convocados não só a pensar, mas também a "dar nossa palavra", e nisso também há escolhas, ganhos e perdas: "drama".

Conclui-se, desta seção, que há vários planos entrelaçados na concepção de "drama" insinuada por Vigotski, como o biográfico, o literário, o reflexológico, o psicológico histórico-cultural, o testamentário intelectual, etc.; mas notamos neles constante (re)elaboração de temas que a cada momento são e não são os mesmos: o da volição ou das escolhas humanas; o de nossa busca de liberdade pessoal e coletiva; o da intervenção do homem em sua própria história. Ademais, é imprescindível destacar que tais temas, no mínimo desde 1924, são indissociáveis da concepção de que esta pessoa que busca por liberdade é um ser social. Em seguida, enfatizarei isto, e indicarei problemáticas emergentes, abertas para estudos posteriores.

\section{PARA CONTINUAR O DIÁLOGO}

Delineadas algumas conclusões formais deste texto na seção anterior, cabe, como é comum em textos do próprio Vigotski (1931/2000, cap. 15), elencar "temas-limite" aos quais não demos tratamento detalhado, mas são relevantes para continuar nosso diálogo. O principal deles é o de que, se o central para a psicologia de Vigotski, no interior da qual está o problema do "drama", for mesmo o "problema da liberdade" (Vigotski, 1932/2010), certamente não é numa acepção liberal, tampouco neoliberal que o termo deve ser entendido. Podemos resgatar pelo menos duas fontes filosóficas, respeitadas por Vigotski, indicativas de algo bastante distinto. Uma delas seria a abordagem "espinosana" sobre a liberdade (Chaui, 1979; 1995), próxima à busca de esclarecimento e superação das superstições e preconceitos, na qual necessitamos nos compor com nossos semelhantes, para construir uma visão crítica do real, da vida pública - portanto, de nós mesmos. Outra seria a orientação engeliana-marxiana, não oposta à primeira, de construção coletiva e classista de um salto do reino da necessidade para o reino da liberdade, na linha de Engels (cf. apresentado acima no presente trabalho).

De modo um tanto mais categórico, posso afirmar que uma postura liberal relativista, que coloque o indivíduo e suas idiossincrasias no centro de tudo, muito menos poderá fazer emergir qualquer liberdade autêntica, isto é, responsável, cooperativa e solidária, pois liberdade não significa uma idílica "plena realização do desejo", por vezes reduzida à atualização de um impulso orgânico, ou descarga energética, o que não passa de outro modo de dizer "servidão". A eleição desse tópico, para dar acabamento ao nosso diálogo, não é aleatória. No presente trabalho pudemos, em certa medida, posicionar o tema da "liberdade humana" junto ao problema do "percurso e acontecimento dramático", pelo qual é necessário e possível decidir sobre o que se deseja fazer e o que se aceitará deixar de fazer - o que não implica nenhuma "solução" catártica definitiva para a tensão gerada pela necessidade de decidir. Concordando com Rubinshtein (1946/1967), quanto a toda escolha envolver uma perda, questiono: acaso apagam-se da memória as perdas de cada escolha nossa?

Feita a escolha, "atuada" a volição, a tensão dos vetores opostos e em rota de colisão pode permanecer, ainda que noutras relações de "hegemonia", pois aquilo de que se abriu mão continuará sendo constitutivo da ação efetiva pela qual se optou, assim como as palavras que dizemos continuam sendo constituídas pelas que foram caladas. Em texto sobre pessoas que aderiram à luta pela terra, uma das entrevistadas diz ter sido consultada pelos pais, ainda criança, quanto a participar ou não. Ela deveria decidir entre $(a)$ ir para a zona rural com seus pais e (b) ficar na cidade com outros familiares; porém seu real desejo era continuar na cidade $e$ junto com os pais. "(...) ela é consultada sobre a adesão e cogita não concordar, mas não suporta não acompanhar a família e então adere" (Melo, 2001, p. 141-142). Tal narrativa ilustra de modo breve e singelo algo profundo e elevado quanto ao caráter da liberdade de escolha de uma pessoa concreta. Mostra também que eleger o melhor dentre duas opções nas quais igualmente haverá perda realiza a essência do que há de dramático na escolha - como dito em texto bíblico (João 19,5) e em Vigotski, com outro sentido: "Ecce homo" (Eis o humano) ${ }^{5}$.

Por fim, como última consideração, mas não menos importante, façamos um pequeno movimento autocrítico quanto à própria eleição do tema do "drama" para nosso diálogo. Quem discorre sobre a

Comumente se traduz de modo pessoal "Eis o homem", como no texto bíblico em que Pilatos nomeia Jesus, referindo-se a uma pessoa em particular "Eis o tal homem". Mas aqui cabe o impessoal. "Homo sapiens", por exemplo, não se refere só ao "varão". "Eis o ser humano", "Eis o humano" são traduções possíveis. 
ação como "drama", por exemplo, arrisca-se ainda a não ter falado com a mesma dedicação sobre a atividade humana como "poï̀sis" (criação) ou "prâxis" (prática), mesmo que disso também fosse imprescindível falar com a mesma dedicação. $\mathrm{Na}$ célebre citação de Vigotski a Marx no texto sobre "A consciência como problema da psicologia do comportamento" (Vigotski, 1925/1991), na qual se diferencia o trabalho humano da atividade da abelha ou da aranha, falta um trecho importante - tanto na edição espanhola quanto na brasileiro1). Citarei aqui, então, o de tradução brasileira feita diretamente do alemão:

\begin{abstract}
Além do esforço dos órgãos que trabalham, é exigida a vontade orientada a um fim, que se manifesta como atenção durante todo o tempo de trabalho (...). Os elementos simples do processo de trabalho são a atividade orientada a um fim [para Nancy: "prâxis" A.D.Jr] ou o trabalho mesmo, seu objeto e seus meios (Marx, 1867/1983, p. 150, itálicos adicionados).
\end{abstract}

Claro está que a prática e a criação humanas são fontes de impasses e constantemente geram situações dramáticas, mas discutir a possibilidade de (re)conversão em "práxis" do drama humano, com seus múltiplos modos de "representação" ou "mímese", fica para outro momento e/ou autores. Só devo explicitar minha franca compreensão de que o "ato de vontade" que tal "drama" envolve e demanda estabelecermos "fins" (ou "teve" - plural de "telos") em "coexistência" com nossos semelhantes (i.e., na produção de acontecimentos coletivos), em nossas relações familiares, na escola, nas associações, na vida cidadã, na luta por transformações sociais radicais; que devem ser partilhados e determinados, e que nos permitam "fazer" e não só "imaginar", "conceber" ou "significar". É evidente que não se pode dissociar o "fazer" (dramático, poético, prático) da "concepção", da "imaginação", da "significação"... Mas uma volição hesitante sempre a "produzir novos sentidos" para situações reais que nunca têm solução, pois a "prâxis" que não se realiza, também pouco contribui para efetivar o projeto espinosano, marxiano, vigotskiano, com o qual se dialoga aqui.

Somos interpelados pelas contribuições de Vigotski a conceber uma atividade volitiva produtora de sentidos que, a um só tempo, crie e produza também objetividade, melhores condições de vida material e potencialização do que temos de propriamente humano; a investigar seriamente sobre o que fazer para que a ação dramática não decaia em prazer diletante ou na dor neurótica de produzir "novos" sentidos e significados para realidades sociais que seguem objetivamente imutáveis, como nossa alienada capacidade de "produzirmos 'novos' sentidos subjetivos" para nossa própria miséria, dor e subserviência (tanto mais ao tratarmos da vivência de outrem), ou nossa já antiga retórica de que tudo a fazer é "criar 'novos' modos de olhar", mesmo ao custo de esse "olhar" ser de indiferença e silêncio em relação à dor do outro, como se não falarmos dela a fizesse deixar de existir. Aqui, contraponho-me abertamente a tais reedições pós-modernas de éticas helenísticas como o "Estoicismo" (suportar a tirania com a força da consciência pessoal) e o "Cinismo" (negar-se a dialogar para evitar transtornos), na esperança de poder retornar à crítica no futuro, se assim me couber, em outro "diálogo no limiar".

\section{REFERÊNCIAS}

Alvarez A., \& del Río, P. (2007) De la psicología del drama al drama de la psicología. La relación entre la vida y la obra de Lev S. Vygotski. In Estudios de Psicología, Volume 28, Number 3, November 2007. p. 303-332.

Aristóteles (334-330 a.n.e./1978) A poética. In Aristóteles Metafísica: livro 1 e 2; Ética a Nicômaco; Poética. (Os Pensadores) São Paulo: Abril Cultural. p. 237-310.

Bakhtin, M. M. (1919-21/1997). Hacia una filosofía del acto ético. De los borradores. Y otros escritos. San Juan: Universidad de Puerto Rico. 249 p.

Bakhtin, M. M. (1963/1997). Problemas da poética de Dostoiévski. 2.a ed. revista. Rio de Janeiro: Forense. 275 p.

Bakhtin, M. M. [Voloshínov, V. N.] (1929/1992) Marxismo $e$ filosofia da linguagem. São Paulo: Hucitec.

Bakthin, M. M. (1952-53/2000) Os gêneros do discurso. In. M. M. Bakhtin Estética da criação verbal. 3. ed. São Paulo: Martins Fontes. p. 277-326.

Barros, E. R. O., Camargo, R. C.,\& Mauch, M. (2011) Vigotski e o teatro - descobertas, relações e revelações. [Dossiê Diálogos com Vigotski: psicologia, educação e arte]. In Psicologia em Estudo: Maringá, v. 16, n. 2. p. 229-240.

Blank, G. (1984);(ed.) Vida y obra de Vigotski. In G. Blank (ed.) Vigotski: memoria y vigencia. Buenos Aires: Cultura \& Cognición. p. 16-55

Boal, A. (1975/1988) O sistema trágico coercitivo de Aristóteles. In A. Boal. Teatro do oprimido e outras poéticas políticas. 5.a ed. Rio de Janeiro: Civilização Brasileira. p. 15-67.

Chaui, M. S. (1979) Espinosa (1632-1677): vida e obra. In B. Espinosa. Pensamentos metafísicos; Tratado de correção do intelecto; Ética; Tratado político; Correspondência. (Os Pensadores). 2.a ed. São Paulo: Abril Cultural. p. V-XXIV

Chaui, M. S. (1995) Espinosa: uma filosofia da liberdade. São Paulo: Editora Moderna, 1995. $111 \mathrm{p}$.

Delari Junior, A. (2000) A linguagem como constitutiva dos papéis sociais. In: Delari Junior, A. Consciência e linguagem em Vigotski: aproximações ao debate sobre a subjetividade. 
Dissertação de mestrado. Campinas: Universidade de Campinas. p. $135-146$.

Dobkin, S. (1982/2009) "Ages and Days" (Semyon Dobkin's Reminiscences). In K. Levitin One is not born a personality: profiles of Soviet educational psychologists. Ohio: Bookmasters. p. $15-28$.

Foucault, P-M. (1966/1992) As palavras e as coisas: uma arqueologia das ciências humanas. 6.a ed. São Paulo: Martins Fontes. 407 p.

Friedgut, T. H., \& Kotik-Friedgut, B. (2008) A man of his country and his time: Jewish influences on Lev Semionovich Vygotsky's world view. In History of Psychology. Vol. 11, No. 1, 15-39.

Gabbi Junior., O. F. (1998) Considerações sobre a eterna juventude da psicologia: o caso da psicanálise. In G. Politzer, Crítica dos fundamentos da psicologia: a psicologia e a psicanálise. Piracicaba: Editora Unimep. 194 p.

Gagnebin, J. M. (1997) O início da história e as lágrimas de Tucídides. In J. M. Gagnebin. Sete aulas sobre linguagem, memória e história. Rio de Janeiro: Imago. p. 15-37.

Guénoun, D. (1992/2003) A exibição das palavras: uma idéia (política) do teatro. Rio de janeiro: Teatro do Pequeno Gesto. 78 p.

Hauser, A. (1953/1998) As origens do drama doméstico. In A. Hauser. História Social da literatura $e$ da arte. 2.a tiragem. São Paulo:Martins Fontes. p. 580-628.

Iaroshevski, M. G. (1993) Perejivanie i drama razvitiia litchnosti (poslednee slovo L. S. Vigotskogo). In: Voprosi Filosofii. N. 3. Moskva: Nauka. 1993. s. 82-91.

Lifanova, T. M. (1996) Polnaia bibliografiia trudov L'va Semionovitcha Vigotskogo. In Vopr. psikhologuii. N. 5. 1996. p. 137-157.

Marx, K. H. (1867/1983) O Capital: crítica da economia política. Volume I, livro Primeiro: O processo de produção do Capital. Tomo 1. Coleção Os Economistas. São Paulo: Abril Cultural. 301 p.

Marx, K. H., \& Engels, F. (1872/2004) Prefacio a la edición alemana de 1883. In K. H. Marx e F. Engels Manifiesto comunista. Madrid: Akal. 000p.

Melo, D. M. (2001) A construção da subjetividade de mulheres assentadas pelo MST. Dissertação de mestrado. Universidade Estadual de Campinas: Campinas. 000p.

Nancy, C. (2003). A razão dramática: sobre o sentido grego de drama. In: Folhetim - Teatro do pequeno gesto. set-dez. p. 9-27.

Politzer, G. (1928/1998). Crítica dos fundamentos da psicologia: a psicologia e a psicanálise. Piracicaba: Unimep.

Politzer, G. (1928-29/1947) La crise de la psychologie contemporaine. Paris: Editions Sociales. Também disponível em: http://www.vigotski.net/textosfr.html\#politzer

Puzirei, A. (1989) L. S. Vigotski [nota biográfica]. In: A. N. Leontiev; A. R. Luria; L. S. Vigootski El processo de Formacion de la Psicologia Marxista. Moscu: Progresso. p. 41-44.

Romanelli, N. (2011) A questão metodológica na produção vigotskiana e a dialética marxista. [Dossiê Diálogos com Vigotski: psicologia, educação e arte]. In Psicologia em Estudo: Maringá, v. 16, n. 2. p. 199-208.

Rubinshtein, S. L. (1946/1967) Principios de psicología general. Ciudad de México: Grijalbo. 767 p.
Shakespeare, W. (1601/1990) Hamleto: tragédia. (Coleção Universidade) Rio de Janeiro: Ediouro. 150 p.

Veresov, N. N. (1999) Undiscovered Vygotsky: etudes on the prehistory of cultural-historical psychology. Frankfur am Main, Berlin, Bern, Bruxelles, New York, Wien: Peter Lang. 281 p.

Veresov, N. N. (2005) Marxist and non-Marxist aspects of the cultural-historical psychology of L. S. Vygotsky. In Outlines. No 1. 2005. p. 31-49.

Veresov, N. N. (2009) Forgotten methodology: Vygotsky's case. In A. Toomela e J. Valsiner Methodological thinking in psychology 60 years gone astray? Charlotte: Information Age. p. 267-295.

Vigotski, L. S. (1916/1999). A tragégia de Hamlet - príncipe de Dinamarca. São Paulo: Martins Fontes. 252 p.

Vigotski, L. S. (1924/2003). A educação estética. L. S. Vigotski, Psicologia pedagógica. Porto Alegre: Artmed. p. 225-248.

Vigotski, L. S. (1925/1999). Psicologia da arte. São Paulo: Martins Fontes.

Vigotski, L. S. (1929/1986) [Konkretnaia psikhologuiia tcheloveka]. In Vestn. Mosk. Un. Ta. Ser. 14 Psikhologuiia, 1986, No 1. p. 5165.

Vigotski, L. S. (1929/2000). Manuscrito de 1929 [Psicologia concreta do homem]. In Educação e Sociedade. N. 71. Campinas: Cedes. p. $21-44$.

Vigotski, L. S. (1930/1994). The socialist alteration of man. In L. S. Vygotsky. Vygotsky The Vygotsky reader. Edited by René van der Veer and Jaan Valsiner. Oxford; Cambridge: Blackwell. P. 175-184.

Vigotski, L. S. (1930/2009). Imaginação e criação na infância. São Paulo: Ática.

Vigotski, L. S. (1934) Mishlenie $i$ retch: psikhologuitcheskie issledovaniia. [pod redaktsei i so vstupitel'noi stat'ei V. Kolbanovskogo]. Moskva, Leningrad: Gosudarstvennoe sotsial'no-ekonomitcheskoe izdatel'stvo. 324 p.

Vygotski, L. S. (1924/1991). Los métodos de investigación reflexológico y psicológicos. In L. S. Vigotski Obras escogidas Tomo I. Madrid: Vysor Aprendizaje y Ministerio de Cultura y Ciencia. p. 3-37.

Vygotski, L. S. (1925/1991). La conciencia como problema de la psicología del comportamiento. In L. S. Vigotski Obras escogidas - Tomo I. Madrid: Vysor Aprendizaje y Ministerio de Cultura y Ciencia. p. 39-60.

Vygotski, L. S. (1927/1991). El significado historico de la crisis de la psicología. In L. S. Vigotski Obras escogidas - Tomo I. Madrid: Vysor Aprendizaje y Ministerio de Cultura y Ciencia. p. 259-407.

Vygotski, L. S. (1930/1991). Sobre los sistemas psicológicos. In L. S. Vigotski Obras escogidas - Tomo I. Madrid: Vysor Aprendizaje y Ministerio de Cultura y Ciencia. p. 71-93.

Vygotski, L. S. (1930-31/2006). Paidología del Adolescente. Capítulo 16: Dinámica y estructura de la personalidad del adolescente. In L. S. Vigotski, Obras escogidas - Tomo IV. 2. ed. Madrid: Vysor Aprendizage y Machado Libros. p. 225-248.

Vygotski, L. S. (1931/2000) Historia del desarrollo de las funciones psíquicas superiores. In L. S. Vygotski Obras escogidas. Tomo III. 2. ed. Madrid: Visor. p. 338-354. 
Vygotski, L. S. (1932-34/2006). El problema de la edad. In L. S. Vigotski, Obras escogidas - Tomo IV. 2. ed. Madrid: Vysor Aprendizage y Machado Libros. p. 251-273.

Vygotski, L. S. (1933-34/2006). Crisis del primer año de vida. In L. S. Vigotski, Obras escogidas - Tomo IV. 2. ed. Madrid: Vysor Aprendizage y Machado Libros. p. 319-340.

Vygotski, L. S. e Luria, A. R. (1930/2007) El instrumento y el signo en el desasrrollo del niño. Madrid: Fundación Infancia y Aprendizaje. $88 \mathrm{p}$.

Vygotsky, L. S. (1926/2007). To A. R. Luria, Zakhar'ino Sanatorium, March 5, [19]26 [L.S. Vygotsky: Letters to Students and Colleagues]. In: Journal of Russian and East European Psychology, vol. 45, no. 2, March-April 2007, pp. 11-60.

Vygotsky, L. S. (1928/1994) The problem of the cultural development of the child. In L. S. Vygotsky The Vygotsky reader. Edited by René van der Veer and Jaan Valsiner. Oxford; Cambridge: Blackwell. p. 57-72.

Vygotsky, L. S. (1931-33/1999). The teaching about emotions. In L. S. Vygotsky The collected works of L. S. Vygotsky. Vol. 6. Scientific legacy. New York, Boston, Dordrecht, London, Moscow: Kluwer Academic/Plenum Publishers. p. 69-235.
Vygotsky, L. S. (1932/2010) Two fragments of personal notes by L. S. Vygotsky from the Vygotsky family archive (Prepared for publication and with coments by E. Zavershneva). In Journal of Russian and East European Psychology, vol. 48, no. 1, JanuaryFebruary 2010, pp. 91-96.

Vygotsky, L. S. (1935/1994) The problem of environment. In L. S. Vygotsky The Vygotsky reader. Edited by René van der Veer and Jaan Valsiner. Oxford; Cambridge: Blackwell. p. 338-354.

Vygotsky, L. S. e Luria, A. R. (1930/1996) Estudos sobre a história do comportamento: o macaco, o primitivo e a criança. Porto Alegre: Artes Médicas. 252 p.

Wertsch, J. V. (1985) Vygotsky and the social formation of mind. Cambridge, Massachusetts and London, England: Harvard University Press.

Endereço para correspondência:

Achilles Delari Junior. Rua Bararuba, 3860, Vila Operária, CEP 87503-040, Umuarama-PR, Brasil.E-mail: delari@uol.com.br.

\section{ERRATA}

O Conselho Editorial da Revista Psicologia em Estudo comunica que o v. 16, n.2 mai/jul de 2011 publicou o seguinte erro de impressão retificado a seguir:

Na página 181 inserir a nota de fim no título do artigo SENTIDOS DO " DRAMA" NA PERSPECTIVA DE VIGOTSKI: UM DIÁLOGO NO LIMIAR ENTRE ARTE E

PSICOLOGIAi, de autoria de Achilles Delari Junior.

Dossiê

Diálogos com Vigotski: Psicologia, Educação e Arte.

i De diferentes maneiras, o " diálogo" tem sido prática social essencial ao longo de toda a história da cultura ocidental, permeando desde a réplica cotidiana aos gêneros discursivos mais sistemáticos. Como prática de convencimento quanto ao já considerado verdadeiro, como busca de entendimento partilhado sobre o até então desconhecido e/ou entrelaçando estes e outros modos de produzir sentido. Além disso, estudiosos como Lev Vigotski (1896-1934), dirão que as relações sociais mediadas pela linguagem, são também constitutivas do psiquismo humano, em sua gênese histórica. Tal influxo de sentidos para a palavra " diálogo" perpassa a proposição deste dossiê, que abordará elos intertextuais entre psicologia, educação e arte. Por um lado, dialogar com as contribuições de Vigotski permite-nos refazer o entendimento sobre nosso objeto de investigação e recriar conceitos e sentimentos sobre nós mesmos. Por outro, dialogar não é apenas acatar um ensinamento convincente, por sábio e profundo que seja, mas implica também, interpretá-lo, questioná-lo, confrontá-lo com a realidade contemporânea, sem o que não há como realmente compreendê-lo. Nessa " via de mão dupla" do processo dialógico reside muito da riqueza deste conjunto de estudos e do desafio com o qual seus autores se confrontaram para produzi-lo. Ao dialogar com autores como Vigotski, portanto, somos interpelados também quanto à dimensão ética de nosso trabalho, convidados a vivermos relações sociais solidárias, que permitam a nós mesmos ir além de nossos atuais limites individuais e coletivos. O leitor está convidado a nos auxiliar nessa tarefa, com sua apreciação crítica e sugestões para aguçarmos nossa leitura do real (Achilles Delari Junior, organizador do Dossiê 


\title{
ERRATA
}

O Conselho Editorial da Revista Psicologia em Estudo comunica que o v. 16, n.2 mai/jul de 2011 publicou o seguinte erro de impressão retificado a seguir:

Na página 181 inserir a nota de fim no título do artigo SENTIDOS DO "DRAMA" NA PERSPECTIVA DE VIGOTSKI: UM DIÁLOGO NO LIMIAR ENTRE ARTE E PSICOLOGIA ${ }^{\mathbf{i}}$, de autoria de Achilles Delari Junior.

\section{Dossiê}

Diálogos com Vigotski: Psicologia, Educação e Arte.

\begin{abstract}
'De diferentes maneiras, o "diálogo" tem sido prática social essencial ao longo de toda a história da cultura ocidental, permeando desde a réplica cotidiana aos gêneros discursivos mais sistemáticos. Como prática de convencimento quanto ao já considerado verdadeiro, como busca de entendimento partilhado sobre o até então desconhecido e/ou entrelaçando estes e outros modos de produzir sentido. Além disso, estudiosos como Lev Vigotski (1896-1934), dirão que as relações sociais mediadas pela linguagem, são também constitutivas do psiquismo humano, em sua gênese histórica. Tal influxo de sentidos para a palavra "diálogo" perpassa a proposição deste dossiê, que abordará elos intertextuais entre psicologia, educação e arte. Por um lado, dialogar com as contribuições de Vigotski permite-nos refazer o entendimento sobre nosso objeto de investigação e recriar conceitos e sentimentos sobre nós mesmos. Por outro, dialogar não é apenas acatar um ensinamento convincente, por sábio e profundo que seja, mas implica também, interpretá-lo, questioná-lo, confrontá-lo com a realidade contemporânea, sem o que não há como realmente compreendê-lo. Nessa "via de mão dupla" do processo dialógico reside muito da riqueza deste conjunto de estudos e do desafio com o qual seus autores se confrontaram para produzi-lo. Ao dialogar com autores como Vigotski, portanto, somos interpelados também quanto à dimensão ética de nosso trabalho, convidados a vivermos relações sociais solidárias, que permitam a nós mesmos ir além de nossos atuais limites individuais e coletivos. O leitor está convidado a nos auxiliar nessa tarefa, com sua apreciação crítica e sugestões para aguçarmos nossa leitura do real (Achilles Delari Junior, organizador do Dossiê).
\end{abstract}

